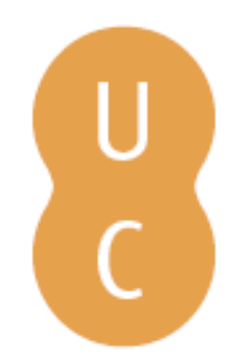

\title{
pompalina
}

\section{Utopias' na literatura neolatina da Companhia de Jesus}

\author{
Autor(es): $\quad$ Urbano, Carlota Miranda
}

Publicado por: Imprensa da Universidade de Coimbra

URL

persistente: URI:http://hdl.handle.net/10316.2/32067

DOI: $\quad$ DOI:http://dx.doi.org/10.14195/978-989-26-0499-2_17

Accessed : $\quad$ 26-Apr-2023 11:43:43

A navegação consulta e descarregamento dos títulos inseridos nas Bibliotecas Digitais UC Digitalis, UC Pombalina e UC Impactum, pressupõem a aceitação plena e sem reservas dos Termos e Condições de Uso destas Bibliotecas Digitais, disponíveis em https://digitalis.uc.pt/pt-pt/termos.

Conforme exposto nos referidos Termos e Condições de Uso, o descarregamento de títulos de acesso restrito requer uma licença válida de autorização devendo o utilizador aceder ao(s) documento(s) a partir de um endereço de IP da instituição detentora da supramencionada licença.

Ao utilizador é apenas permitido o descarregamento para uso pessoal, pelo que o emprego do(s) título(s) descarregado(s) para outro fim, designadamente comercial, carece de autorização do respetivo autor ou editor da obra.

Na medida em que todas as obras da UC Digitalis se encontram protegidas pelo Código do Direito de Autor e Direitos Conexos e demais legislação aplicável, toda a cópia, parcial ou total, deste documento, nos casos em que é legalmente admitida, deverá conter ou fazer-se acompanhar por este aviso.

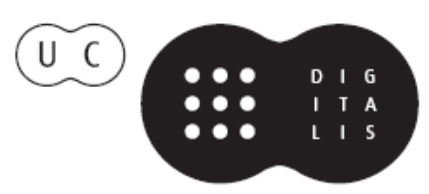


Maria de Fátima Silva

Coordenação

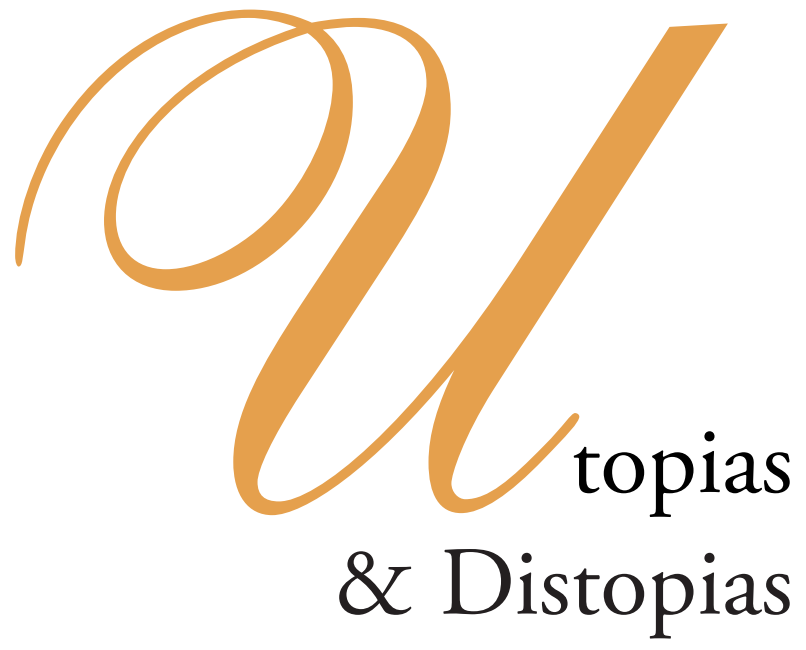




\section{COORDENAÇÃO EDITORIAL \\ Imprensa da Universidade de Coimbra \\ Email: imprensauc@ci.uc.pt \\ URL: http://www.uc.pt/imprensa_uc}

\section{CONCEPÇÃO GRÁFICA}

António Barros

Pré-IMPRESSÃo

Tipografia Lousanense, Lda.

EXECUÇÃO GRÁFICA

Tipografia Lousanense, Lda.

ISBN

978-989-8074-74-4

DEPósito LEGAL

289002/09

OBRA PUBLICADA COM O APOIO DE:

Centro de Estudos Clássicos e Humanísticos

Faculdade de Letras da Universidade de Coimbra

FCT Fundação para a Ciência e a Tecnologia

MINISTÉRIO DA CIÊNCIA, TECNOLOGIA E ENSINO SUPERIOR Portugal 
Maria de Fátima Silva

Coordenação
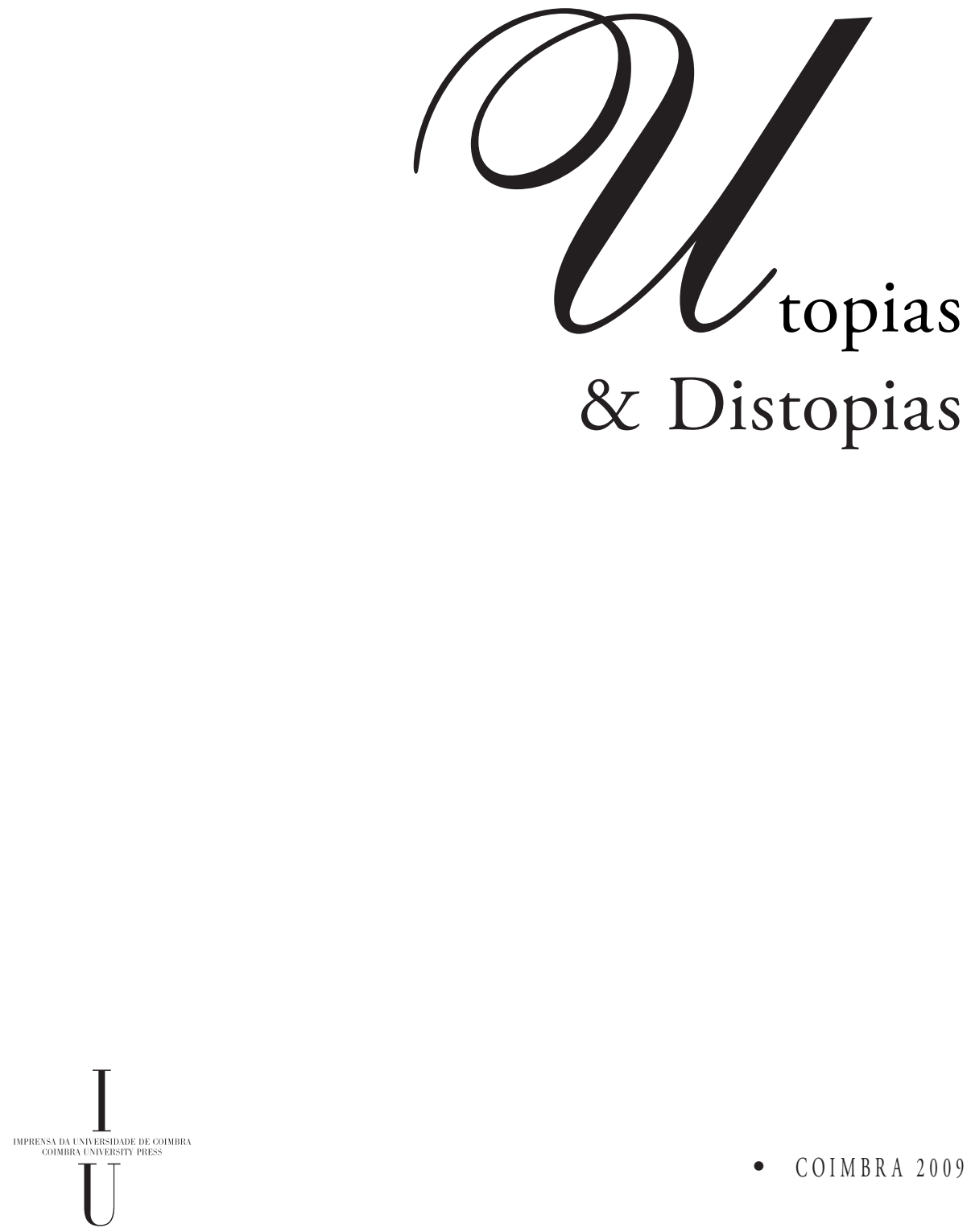

- colmbra 2009 



\section{Carlota Miranda Urbano}

\section{'UTOPIAS' NA LITERATURA NEOLATINA \\ DA COMPANHIA DE JESUS}

1. Considerar a possibilidade de articular 'utopias' com a Literatura jesuítica neolatina remeteu-me imediatamente para o seu 'lugar fundador'. Refiro-me ao 'lugar fundador' da Companhia de Jesus, mas talvez também a um lugar inspirador e mais ou menos veladamente presente no imaginário de toda a literatura jesuítica. Esse 'lugar fundador', quase mítico, é a conversão de um cavaleiro seduzido pelos ideais cavaleirescos que, depois de um grave acidente de guerra, ${ }^{1}$ muda radicalmente a sua vida mediante um processo de transformação interior que lentamente se foi plasmando e passando ao texto dos Exercícios Espirituais. Este pequeno livro, se não é o texto fundador da Companhia de Jesus, é a sua pré-história, tão relevante do ponto de vista da identidade que o podemos reconhecer como traço quase omnipresente na obra literária, sobretudo poética, desta Ordem Religiosa, nos seus primeiros séculos de vida.

Como se sabe, os Exercícios Espirituais constituem uma proposta de auto-análise organizada para 30 dias, metodicamente divididos em quatro semanas, cada semana em dias, em pontos de meditação e de contemplação. Nesta proposta, St. Inácio de Loyola faz grande uso da imaginação em várias das suas meditaçóes, convidando o exercitante a fazer a chamada 'composição do lugar', a imaginar o visível e o invisível, a ver com a vista imaginativa, quer o lugar material da realidade a contemplar, quer a alma e o espiritual ( Exercícios $\$ 47$ ). O exercitante deve, então, compor o lugar que não vê, para que o veja com a imaginação e lhe dê uma existência no plano da interioridade.

Todas as contemplações devem ser preparadas por esta composição utópica, inclusive a meditação fundamental, que é ponto de referência e pano de fundo de todos os Exercícios: a meditação do 'chamamento do Rei temporal-ajuda a contemplar a vida do Rei eterno’ (Exercícios $\$$ 91-98). No início da Segunda Semana que contemplará o

\footnotetext{
${ }^{1}$ Inácio de Loyola foi gravemente ferido em Maio de 1521 por uma bala de canháo quando defendia o castelo de Pamplona do cerco francês de Francisco I. Sujeito a uma difícil operaçáo para recuperar a perna direita que fora atingida, teve uma longa convalescença que ocupou com a leitura da Vita Christi e do Flos Sanctorum por lhe faltarem os bons romances de cavalaria que costumava ler. A circunstância do acidente e aquelas leituras deram ocasiáo a uma mudança profunda na vida do cavaleiro que deixou a espada e se deu a outras 'lutas'.
} 
mistério de Jesus-Homem e antes do momento fulcral da 'eleição' ${ }^{2}$ para que todos os Exercícios convergem, o 'chamamento do Rei temporal' funcionará como chave de leitura para as futuras contemplaçóes. Trata-se de uma parábola fundamentalmente cristológica que confere a Jesus os títulos de Rei, Senhor, Cristo, Príncipe Eterno e, traço do inegável humanismo inaciano, parábola que fundamenta no Filho do Homem toda a História da Salvação, que toma o homem como o lugar da decisão e da acção, realizando plenamente a sua humanidade no encontro com Deus.

Hugo Rahner, comentador dos Exercícios, considera que esta meditação do Reino é o próprio fundamento de todo o seu percurso. ${ }^{3}$

Como Rotsaert, penso que o momento da 'eleição' a fazer - a eleição da vontade divina para melhor servir o Reino - é o eixo estrutural dos Exercícios, ou como escreve o autor, o coração que os estrutura: "L'élection est comme le coeur même qui structure l'expérience des Exercices". ${ }^{4}$ O Reino é, no entanto, fundamental como pano de fundo, e a sua imagem está constantemente presente, centrada na pessoa do Rei. O serviço desse Rei é a utopia, o ideal efectivamente buscado na acção, sob o lema ad maiorem Dei gloriam.

Esta é a utopia mais presente e inspiradora na literatura jesuítica. Uma das suas mais belas e espantosas inspiraçóes foi sem dúvida a utopia do Quinto Império do P. António Vieira cujo quarto centenário celebramos este ano. Como escreve António Lopes, o seu Quinto império não é senão o Reino de Cristo na Terra, ${ }^{5}$ e Arnaldo do Espírito Santo reforça esta identificação: "A esperança na consumação do Reino de Cristo na Terra perpassa por toda a obra de Vieira”. Na sua visão da História, o Quinto império consiste precisamente na consumação do reinado temporal e espiritual de Cristo na Terra. ${ }^{6}$

Acho pertinentemente significativo o termo 'esperança'. Com efeito, parece-me que esta é a palavra que melhor caracteriza todas as utopias que se inspiram mais ou menos directamente na utopia inaciana do Reino. Esta é, com efeito, uma utopia da esperança, uma utopia, por definição, escatológica; uma utopia que vive do que já começou, do que se deseja e espera, e do próprio acto de esperar.

Trata-se de uma utopia que coloca a idade do Ouro, não no passado irrecuperável de um paraíso perdido mas, pelo contrário, na possibilidade, sempre em aberto, do futuro. É no futuro, que é possível a perfeição e a consumação de um mundo que, fecundado pela aliança entre a praxis humana e a graça divina caminha para o sentido total. Essa aliança, na utopia inaciana tem lugar no 'chamamento do rei eterno' e na indissociável 'eleição' do exercitante.

\footnotetext{
2 Feita no final da Segunda Semana, $\$ 188$, ela vem sendo preparada desde $\$ 169$, 'preâmbulo para fazer uma boa eleição'.

${ }^{3}$ Hugo Rahner, La Genèse des Exercices, trad. do alemão de Guy de Vaux (Paris, Collectio Christus, 1989), p. 49.

${ }^{4}$ Mark Rotsaert SJ, 'L'originalité des Exercices spirituels d'Ignace de Loyola sur l'arrière-fond des renouveux spirituels en Castille au début du seizième siècle', Ignacio de Loyola y su tiempo. Congresso Internacional de Historia (1991), Juan Plazaola ed. Bilbao, pp. 329-341.

5 A. Lopes, 'Os 74 anos de evolução da «utopia» de Vieira', (Terceiro centenário da morte do Padre António Vieira, Congresso Internacional, Actas, Braga, 1999, 3 vol), pp. 857-880, cfr. 2, p. 871.

${ }^{6}$ A. do Espírito Santo, 'Aspectos do pensamento de Vieira na Clavis Prophetarum' Terceiro centenário da morte do Padre António Vieira, Congresso Internacional, Actas, Braga, 1999, 3 vol), pp. 909-918, cfr. 2, p. 909.

7 Bartolomeu Pereira, Paciecidos libri duodecim, (Coimbra, 1640).
} 
2. A minha investigação na Literatura neolatina da Companhia de Jesus tem incidido fundamentalmente na primeira metade do séc. XVII. É pois no âmbito deste breve arco temporal que posso afirmar que a literatura neolatina jesuítica é rica em expressôes literárias de utopias a vários níveis.

2.1 Um desses níveis da utopia prende-se com a construção do texto literário e com o recurso à utopia como tópico literário. $\mathrm{Na}$ poesia épica de modelo clássico homérico-virgiliano, encontramos frequentemente o recurso ao motivo do reino ou da cidade ideal, como um lugar perfeito, onde as virtudes são naturais, onde a felicidade e a plenitude sáo tangíveis. Encontramos o recurso a este motivo, por exemplo, na epopeia neolatina de Bartolomeu Pereira, o Paciecidos libri duodecim $(1640)^{7}$ que segue explicitamente aquele modelo de épica clássica. Nesta narrativa, alguns jesuítas missionários no Japão, depois de terem sido forçados ao exílio em Macau, regressam clandestinamente e, perseguidos e presos, são executados na fogueira em Nagasaki. São várias as ocasiôes em que o poeta, articulando história e ficção, vestindo os factos (que conhecemos através das narrativas das $\operatorname{Cartas}_{\hat{A} n u a s^{8}}$ ) com o fantástico evocativo dos temas clássicos da epopeia, convoca diante do leitor, não as cidades ou reinos míticos e lendários mas as comunidades e as casas ideais, bem-aventuradas, iluminadas e abençoadas pela caritas.

Quando Francisco e os companheiros deixam contra-vontade as praias do Japão e se despedem da sua igreja perseguida e entregue às chamas, aportam em Macau, onde são recebidos na Casa da Companhia. Aqui, o poeta desenvolve o tema clássico da hospitalidade e do banquete oferecido ao herói exilado, ${ }^{9}$ mas para evocar o esplendor da virtude e da concórdia que une os irmáos da Companhia. Em vez de celebrar a habitual riqueza e prodigalidade de quem recebe, o poeta reinterpreta, no tema da pobreza evangélica, o tema clássico da aurea mediocritas. Neste episódio que encerra o canto I do poema, ${ }^{10}$ o poeta como que profetiza com as suas palavras o banquete escatológico e messiânico que na linha do Livro do Apocalipse está associado ao martírio (tema central do poema). É o amor que serve as iguarias, que congrega os irmãos e que reina naquela refeiçáo pobre, tornada sagrada pela presença dos irmãos, verdadeira essência da Ambrósia.

Mais tarde, em analepse, o herói recorda um outro lugar onde foi recebido, desta vez como náufrago. Na viagem para o Japáo, Francisco enfrenta um naufrágio de que sobrevive, nadando até à praia. Ao ver os cadáveres dos companheiros, sepulta-os e assinala as suas sepulturas com uma cruz. É entáo que lhe aparece uma jovem, Piedade, para lhe agradecer este gesto e, qual Nausícaa a Ulisses, ${ }^{11}$ para lhe indicar o

\footnotetext{
${ }^{8}$ Espécie de relatórios anuais que as casas da Companhia enviavam para os seus provinciais com os principais acontecimentos, quer da vida e do progresso da evangelização levada a cabo pelos seus membros, quer dos factos da vida local.

${ }^{9}$ Recorde-se o acolhimento de Ulisses no palácio dos Feaces, em $\mathrm{Od}, 8$ ou o de Eneias no palácio de Dido na Eneid, 1.

${ }^{10}$ Cfr. 1, pp. 446-530.

${ }^{11} \mathrm{Od}, 6$, pp. 110-320. O passo evoca também o encontro de Eneias com a sua mãe. De resto, há até alguma semelhança num dos versos: 9, pp. 321-322: "Tunc mihi se mediis uirgo dedit obuia arenis/ Funereos accinta habitus (...)". Coteje-se o passo virgiliano: "Cui mater media sese tulit obuia silua/ uirginis os habitumque gerens (...)”. Eneida 1, pp. 314-315.
} 
caminho até à casa de um agricultor que lhe prestará todo o auxílio. Francisco póe-se a caminho e, quando avista as chaminés fumegantes das cabanas dos pastores, encontra Alofo e a família, o agricultor abastado de que lhe falara Piedade, e que conduzia o rebanho de cabras para ordenhar. Trata-se de um agricultor abastado, mas o quadro que o poeta descreve é o de uma família simples e feliz que vive da pastorícia. Todos, o velho Alofo, a sua mulher, as noras e os netos, se envolvem no trabalho da ordenha num clima naturalmente bom. Ao ver o náufrago, deixam o rebanho, preparam uma fogueira para que ele se aqueça e servem-lhe uma refeição farta, onde náo falta o leite em espuma, acabado de ordenhar. ${ }^{12}$

Finalmente, quando já perto da execução fazem uma pausa na viagem para Nagasaki, os heróis são recebidos por um piedoso agricultor cristão em Fimi. Esta paragem, documentada nas fontes históricas do poema, encontra-se elaborada de forma a servir duas intençóes: a caracterização da escolta dos prisioneiros como insolente e bárbara, dominada pelo excesso e pela violência e, por contraste, a caracterizaçáo do ambiente de paz e caridade com que os heróis são recebidos pelo humilde agricultor cristão. Quando o chefe da escolta, Asondo, pensava confiar os prisioneiros a um terrível inimigo dos cristãos e lhe recomenda a maior severidade, não sabia que aquele pobre agricultor era cristão desde menino. Este, quando soube que tinha em casa os padres jesuítas, preparou-lhes com toda a devoção uma refeição e um leito para a noite. O ambiente é propício a que os heróis troquem palavras sobre o martírio que se aproxima e o agricultor e a sua casa são merecedores de um hino que exalta a sua frugalidade, a pobreza e a paz que neles reina. Os versos que terminam o episódio profetizam ao agricultor um destino de mítica e prodigiosa abundância, reforçando o carácter utópico de mais esta cena de hospitalidade.

Em todos estes casos, estes lugares são abençoados pelo esplendor da virtude, pela concórdia, pela justiça, são marcados não tanto pela mítica abundância e prodigalidade da natureza mas pela abundância espiritual. Todos eles estão associados ao motivo clássico da hospitalidade e referem-se simbolicamente ao topos da comunhão eucarística.

2.2 Outro nível de utopia recorrente na Literatura neolatina jesuítica, embora não seja exclusivo dela, é o desenvolvimento de um genus literário que se auto-designa geralmente como poema heróico ou épico mas cuja narrativa consiste no discurso do orador, composto sobretudo da descrição de um cortejo ou de uma apoteose que o poeta imagina e faz imaginar convocando o leitor/ouvinte a uma utopia. Um exemplo é o De Apotheosi S. Francisci Xauerii libri tres ${ }^{13}$ do P. Francisco Macedo, uma epica descriptio do cortejo triunfal e apoteótico das festas da beatificação de Francisco Xavier. A descrição é de tempos a tempos interrompida por visóes místicas do poeta que convocam o leitor/ouvinte a um mundo utópico e imaginado pela poesia, no ambiente fantástico e maravilhoso da visão onírica do poeta, bastante ao gosto da estética barroca.

12 'Pocula feruenti fumant spumantia lacte.' Cfr. 9, p. 367.

${ }^{13} \mathrm{O}$ poema vem publicado no Corpus Illustrium Poetarum Lusitanorum qui latine scripserunt, ed. António do Reis (Lisboa, 1748, tomo VII) pp. 22-77. Sobre este poema veja-se C. Miranda Urbano, 'S. Francisco Xavier e a poesia hagiográfica novilatina em Portugal’ Humanitas 58 (2006) pp. 369-390. 
2.3 Outro nível ainda é a activação de mitos e utopias nacionais, como, por exemplo, o sebastianismo. A primeira metade do séc. XVII é especialmente rica na expressão literária desta utopia messiânica. Dentro destes mitos nacionais podemos considerar alguns, verdadeiros mitos hagiográficos cuja canonização reforça com um efeito identitário nacional, a auto-estima, a identidade e os fundamentos da soberania do reino. Representados como heróis na sua acção na terra, são também muitas vezes representados na apoteose da sua canonização e da glorificação celeste. Nesta medida, enquanto projectados para lá das fronteiras da morte na cidade celeste, esses mitos têm uma dimensão utópica.

2.4 Finalmente, na literatura jesuítica neolatina encontramos também utopias, no seu sentido mais contemporâneo, como ideais activamente procurados. Activamente procurados, por exemplo, por meio da palavra e do discurso literário, na consciência humanista de que o domínio da palavra é fundamental à mediação humana.

3. Destes três (níveis) propomos aqui um exemplo literário: o Pro Elisabetha Regina Lusitanorum recens consecrata. Poema epicum siue heroicum publicado em 1626, composto em 1625 para um concurso poético promovido pela Universidade de Coimbra, celebrativo da canonização da Rainha Santa em 1625, pelo Papa Urbano VIII. O seu autor, o então jesuíta Padre Francisco Macedo, viria a notabilizar-se mais tarde, como Fr. Francisco de St. Agostinho de Macedo, ao serviço da legitimação de D. João IV na Europa.

Quando Santa Isabel de Portugal foi canonizada, havia motivos de sobra para Coimbra festejar. A notícia era esperada há muito, por isso foi celebrada com grandiosas festas, como de resto era habitual fazer-se então. ${ }^{14}$

Às celebraçôes organizadas por D. João Manuel, bispo de Coimbra, seguiram-se seis dias de festa na cidade, em que colaborou a Universidade, promovendo o certame poético a que acima nos referimos e no qual discursaram vários oradores. Um ano depois, este certame foi publicado em Coimbra, incluindo no início as oraçôes latinas e os sermóes de todas as festas.

O Pro Elisabetha Regina, o poema que abre esta colecção, classificado pelo autor como épico, ou heróico, consiste na encenação de uma oratio em que o poeta descreve um cortejo imaginário. Trata-se de uma epica descriptio que convoca junto do leitor a utopia da apoteose de St. Isabel à sua entrada gloriosa nos céus.

Embora se trate de um poema hagiográfico e portanto com o objectivo formal de celebrar as virtudes da Rainha, podemos considerar este poema um verdadeiro instrumento de intervenção política. Com efeito, esta composição poética faz a interpretação dos factos recentes, a canonização da Rainha, em função de um ideal conscientemente procurado num futuro que se espera próximo. Santa Isabel foi canonizada e, utopicamente, a soberania foi restituída a Portugal. Mais adiante veremos como. Os versos

\footnotetext{
${ }^{14}$ Estas celebrações encontram-se descritas num manuscrito anónimo que A. G. da Rocha MADAIL, 1. Conservador da BGU transcreveu e publicou na Revista literária O Instituto, 90 (1936) pp. 4-36. Reza o título do folheto manuscrito: "Relação das Grandiosas Festas que na Cidade de Coimbra hoje por novo titulo ditosa Cidade fez o Illustrissimo Senhor Dó Ioão Manoel Bispo Conde, á Canonização de Sancta Isabel Rainha de Portugal”.
} 
de Francisco Macedo procuram fazer o auditório/leitor acreditar que é possível, que é vontade divina, que está prestes a acontecer e a ter lugar a utopia da recuperação da autonomia da Coroa portuguesa. Nessa medida, o poema adquire uma dimensão profética capaz de actuar ao nível do presente, inspirando, estimulando, desenvolvendo e exaltando sentimentos de adesão à causa autonomista e promovendo a resistência à monarquia dual.

Embora seja o motivo central da composição, a Rainha Santa é celebrada, não isoladamente como heroína protagonista de uma gesta heróica, mas integrada no centro de uma constelação cuja teia é a sucessão dinástica desde o fundador, D. Afonso Henriques, até D. Sebastião. A omissão da dinastia filipina é, naturalmente, intencional.

Antes de descrever o cortejo, o poeta é como que arrebatado misticamente, e só por isso pode fazer-nos a descriçáo dessa visão utópica que se segue:

Mas, porque hei-de eu tentar abarcar tais coisas em humildes versos?

Não sou transportado às alturas? Que loucura me arrebata?

Subo às nuvens altas, suportando o velho Febo

e, suspenso, cada vez mais perto dos astros,

vejo rasgar-se a abóbada celeste, vejo os anjos vindos do céu

erguer aplauso, e um cortejo triunfal guiado através das nuvens:

honra imensa de Isabel, sinal do seu Triunfo. ${ }^{15}$

O poeta vê então descer deste céu 'rasgado' os heróis em cujo reinado outrora se estabeleceu o império lusitano numa idade de ouro. O Cortejo abre com D. Afonso Henriques cujo escudo ostenta as armas delapsa caelo, ${ }^{16}$ numa alusão ao Milagre de Ourique. Traz ainda, e por se identificar com Cristo cruxificado da aparição de Ourique, uma coroa de espinhos, e não de pedras preciosas. Omitimos a referência exaustiva a todos os monarcas do reino, cada um evocando de algum modo as virtudes da Santa, onde não faltaram D. Dinis e D. Afonso para exaltar as virtudes da Rainha nos esforços pela paz no reino.

Dessa omissão salvamos a referência a D. Manuel, que o poeta reconhece pelo globo que o monarca traz na mão, invocando sobre si mesmo a vocação universalista de Portugal. Este rei, celebrado como aquele que venceu o oceano e os monstros do mar, que aos mundos desconhecidos levou o nosso estandarte, que subjugou a barbárie e os povos infiéis, ostenta, não uma, mas todas as obras de caridade da Santa junto dos pobres, dos doentes e dos presos.

Encerram este cortejo triunfal dois heróis. Trata-se do Cardeal D. Henrique, e de D. Sebastiáo.

Um traz consigo o ceptro e as insígnias do reino

Ao outro, porém, (ainda que revestido todo o corpo numa aura brilhante)

15 Sed quid haec humili compreendere carmine tento?/ Non feror ad superos! Quis me rapit? Auferor altas/In nubes, Phoebi patiens maioris, ab astris/ Afflatus propius, uideo discedere caelum,/ Emittique polo Superos, plausumque ciere,/Atque triumphalem duci per nubila Pompam:/ Elisabethae ingens decus, ac insigne Triumphi. vv. 32-38.

16 ...delapsaque caelo/ Stemmata fert clypeo... vv. 50-51. 
encobre-o uma nuvem em sua volta que traz aos meu olhos um vulto que não consigo distinguir.

(...) olho de novo para o outro, visivel no meio da luz:

Reconheço então Henrique, reconheço a última glória do reino de Portugal.

(...) Como a nuvem não me permite distinguir o vulto do outro,

fixo o olhar no escudo onde distingo um nobre emblema,

desenhado a ouro e ornado de pedras preciosas.

É então que vejo ai as batalhas no campo coberto de sangue,

ai vejo o exército disperso, as tropas desoladas,

$o$ estandarte por terra e o solo coberto de cadáveres. ${ }^{17}$

E o poeta continua a descrição do que vê neste campo de batalha: as insígnias de Portugal estão por terra, a coroa real tombada, um rosto pálido, sujo de poeira, com os cabelos desalinhados pela face, jaz por terra. Prossegue depois numa apóstrofe ao 'desejado':

Não mais vos escondeis D. Sebastião,

ó breve alegria deste reino, ó vã esperança dos vossos,

ó saudade, cuidado que não tem repouso, dor eterna, posto que justa. ${ }^{18}$

O poeta, porém, vê que o fulgor daquele rosto reaparece, divisa no seu olhar um sorriso, pois $\mathrm{St}^{\mathrm{a}}$ Isabel vem em auxílio dos portugueses.

É que Isabel, apiedada dos sofrimentos de Portugal, virá em seu auxilio, dita-lhe que espere na salvação $e$ aos aflitos manda acreditar em melhores dias.

Então estende a mão àquele que jaz caído, soergue aquele que se esforça por pôr de pé no pó,

a custo arrasta os membros enfermos,

$e$, apoiando-o, de novo o eleva às alturas do poder;

devolve-lhe o ceptro e a coroa. ${ }^{19}$

No final do cortejo vem St. Isabel, no carro reluzente fabricado por mãos divinas, rodeada de anjos que tocam, cantam e aplaudem em festa. $\mathrm{O}$ poeta dirige-se-lhe num hino de louvor que se cruza com a prece. Se Sta ${ }^{a}$ Isabel recorda ainda algum amor da mãe que na terra foi, cuide agora de Portugal:

17 Sed tamen ille gerit sceptrum, atque insignia regni./ At uero alterius (quamquam clarissimam totum/ Lux obeat corpus) nubes obiecta recondit,/ Atque aufert uultum, nec noscere fas est/ (...) Ergo alium rursum inspicio, qui luce patescit/ in media: nosco Henricum, nosco ultima Regni/ Lysiaci ornamenta (...) Et quoniam alterius nubes discernere uultum / non sinit, in clypeum defixus lumina, pulchrum/ Stemma legam, descriptum auro, gemmisque coruscum./ Atque hic sanguineo spectantur praelia campo,/ Disiectasque acies, desolatosque maniplos,/ Lapso solo uexila, et strata cadauera cerno. vv. 348-351; 353-355; 368-373.

18 (...) Nec jam te absconde Sebaste,/ Laetitia o Regni breuis, o spes uana tuorum,/ O desiderium, cura importuna, dolorque/ Aeternus, quanquam iustus Corpus...op. cit. vv. 381-384, op. cit. p. 91.

19 Scilicet Elisabeth Lysiae miserata labores,/ Auxilium latura monet sperare salutem, / Et docet afflictis melius confidere rebus./ Ergo manum labenti offert, et puluere in ipso/ Conantem attoli, uix et genua aegra trahentem/ Sustentatque, leuatque, iterumque extollit in altum/ Imperii culmen; sceptrum, et diadema reponit..vv. 390-396. 
Zelai, pois, pela defesa de Portugal, guardai-o sob o vosso braço protector, a nação que outrora, na guerra, governastes soberba em sua grandeza, agora alquebrada, restaurai-a, erguei-a, que jaz prostrada.

Mas, que digo eu? onde estou? Sta Isabel não há-de erguer essa que jaz, pois ergueu-a já, restituiu-lhe as insignias da sua glória primitiva, colocou-a no seu trono antigo, devolveu-lhe a honra e a glória perdidas, $e$ a nós, indignos, de novo trouxe a raça e o vigor pátrios. ${ }^{20}$

Na sua visão mística o poeta vê já os efeitos da intercessão da recentemente canonizada St. ${ }^{a}$ Isabel que devolve a honra e o vigor à nação pátria.

Animados pela Rainha Santa, os portugueses hão-de resgatar o seu nome que jaz sepulto, para que se erga do pó, rediviva, a sua glória.

Era isto, ó Altíssimo, continua o poeta, que guardáveis para Portugal, depois de tantos anos de luto e sofrimento:

Ó feliz geração a nossa, ó felicidade destes tempos, e felizes de nós, a quem foi dado viver para ver a nossa Rainha acrescida ao número dos santos. ${ }^{21}$

A felicidade que provém da canonização de St. ${ }^{a}$ Isabel redime em absoluto a dor do tempo presente que o poeta já vê transformado pelo desejo que voa até à utopia do Reino Celestial. No final, porém, o poeta regressa ao presente. Os seus últimos versos são uma peroratio à Pátria enlutada, para que deponha as vestes fúnebres, enxugue as lágrimas dos seus olhos e de novo se levante, pela mão de $\mathrm{St}^{\mathrm{a}}$ Isabel, no esplendor da sua coroa, tal como outrora a Europa a via: vencendo pela espada a África, rasgando o mar alto, chamando ao seio da Fé e à Lei de Cristo os povos longínquos da Ásia, aniquilando cidades, debelando tiranos, trazendo de todo o mundo nobres vitórias. ${ }^{22}$ É o que lhe anuncia, lá de seus altares acabados de erguer, St ${ }^{\mathrm{a}}$ Isabel, deixando como penhor da sua promessa, as suas relíquias.

4. É bem visível a expressão da utopia nos passos que citámos. O poema faz uma espécie de reconstrução mítica da História que se veio a generalizar e propagandear depois da Restauraçáo, segundo a qual Portugal era detentor de um destino sagrado que consistia, em última instância, em evangelizar o mundo. $\mathrm{O}$ pano de fundo é a visível aliança entre o Rei temporal, aqui presente na sucessão de reis desde a fundação de Portugal, assinalada pelo Milagre de Ourique, e o Rei eterno que se revela na canonização da Rainha. Esta aliança acaba de se manifestar na apoteose de Santa Isabel, já inteiramente assumida pela eternidade.

Com esta utopia como pano de fundo, as décadas de ruína e de decadência que Portugal atravessava náo podiam deixar de ser vistas como passageiras e transitórias, para que o seu destino se cumprisse. Note-se que este mito da 'perenidade' do Reino

\footnotetext{
${ }^{20}$ Atque age tutelam Lysiae, et sub numine serua/ Laeta tuo, et quam olim belloque, opibusque superbam/ Rexisti, fractam refice, atque attolle iacentem./ Quid loquor? aut ubi sum? non Elisabetha iacentem/ Eriget; erexit iam, atque ornamenta prioris/ Restituit famae, primaque in sede locauit:/Virtutemque decusque amissum reddidit, et nos/ Degeneres genus ad patrium, roburque reduxit . vv. 434-441.

${ }^{21} \mathrm{O}$ felix aetas, felicia tempora, nosque/ Felices! Quibus est permissum uiuere, cum iam/ Reginam caelo adscriptam , Diuumque relatam / In numerum uididsse datum est! (...)vv. 461-465.

${ }^{22}$ Vv. 475-497.
} 
de Portugal, particularmente activo no primeiro quartel do séc. XVII, conhecera anteriores e pertinentes momentos de estruturação, como é o caso da obra historiográfica de Fernando de Oliveira, escrita por volta de 1580 e recentemente editada e estudada por José Eduardo Franco. ${ }^{23}$ No seu interessante estudo, o autor observa pertinentemente como Portugal, ameaçado pela crise, obedeceu à necessidade imperiosa de rever a sua história para intervir no presente, com o objectivo de resistir à hegemonia espanhola, desenvolvendo um verdadeiro 'mito da nação'. Lembremos que Portugal se afirmou como reino em ambiente de reconquista, de cruzada, e que depois revelou especiais capacidades de expandir a cultura latina e cristã num movimento de abertura de novas vias nas relaçôes internacionais, de expansão económica, de proselitismo religioso, movimento interrompido por uma crise geral da nação que se conjugou com a uniáo das coroas de Portugal e Espanha e seus efeitos agravantes naquela crise.

Como forma de resistência à própria crise, a força da utopia consegue recuperar velhos mitos nacionais e idealizar os heróis do passado, sem que isso signifique um regresso. Mitificando desde o passado longínquo ao passado recente, este último aqui objecto de uma mitificação hagiográfica, eles contribuem decisivamente para o fortalecimento da consciência colectiva de independência e de soberania.

Entre a recuperação e reconstruçáo de velhos mitos destaca-se o Milagre de Ourique, que, sobretudo desde a versão de Duarte de Galvão ${ }^{24}$ no séc. XVI, oferece alicerce e autoriza o mito da vocação universalista de Portugal. A figura de D. Afonso Henriques, cuja veneração se intensifica precisamente no séc. XVII, surge, aliás, frequentemente associada a D. Sebastiāo. Mas também a figura de St. ${ }^{a}$ Isabel é ela própria um mito nacional, capaz de mobilizar o auditório que celebra a sua canonização, no sentido de acreditar na utopia, de desejar activamente e servir um ideal de nação que a própria Santa Isabel serve profeticamente. De certo modo, a canonização da Rainha activa escatologicamente a utopia da recuperação do reino. $\mathrm{Na}$ sua visão onírica deste cortejo, o poeta vê essa recuperação e torna-a utopicamente presente diante do leitor/ouvinte.

Se a utopia é actuante enquanto fonte de futuro, esta foi uma utopia eficaz, porque também preparou o terreno para a consolidação do movimento que possibilitaria a aclamação de D. João IV, movimento que mais tarde pugnou pela sua legitimação e reconhecimento aos olhos das outras naçóes.

Nascida do desejo de soberania, a utopia convocada por Francisco Macedo a estes versos, ganha sentido acrescido se a olharmos tendo como pano de fundo a utopia escatológica do Reino de Cristo na terra, que já começou mas ainda não se completou. A canonização da rainha é o sinal divino, em que o poeta espera, sinal de que a recuperação da soberania já chegou e há-de cumprir-se. Esperar e acreditar nessa recuperação é torná-la possível. A utopia foi, então, eficaz, ao acreditar na recuperação da soberania portuguesa como, de facto, viria a acontecer em 1640, 15 anos depois. 2000)

23 J.E. Franco, O Mito de Portugal. A primeira História de Portugal e a sua função política (Lisboa, ${ }^{24} \mathrm{Na}$ sua Chronica de El-Rei D. Affonso Henriques (Lisboa, Bibliotheca de Classicos Portuguezes, 1906). 
Não podemos alhear desta eficácia os mestres da Companhia de Jesus que no púlpito e na cátedra, não obstante as recomendaçōes superiores de se absterem de intervir na polémica da autonomia das coroas portuguesa e espanhola, não se inibiam de alimentar no seu público o desejo utópico de recuperar a soberania do reino. 



\section{Série}

\section{Documentos}

Imprensa da Universidade de Coimbra

Coimbra University Press

2009

- $\mathrm{U}$

C • 